\title{
ŚLADY EGZEGEZY FILONA ALEKSANDRYJSKIEGO W DE MONASTICA EXERCITATIONE NILA Z ANCYRY
}

W swoim manifeście życia monastycznego, którym jest pismo De monastica exercitatione, Nil z Ancyry († ok. 430) uprawia egzegezę alegoryczną na użytek ascezy. Dużo częściej sięga do Starego Testamentu aniżeli Nowego. Naliczyliśmy ponad trzydzieści miejsc, w których nie poprzestaje na samym odniesieniu do Biblii, ale podejmuje się ich przenośnej wykładni. Z tej liczby kilka nie dotyczy wprost ascezy; w kilku miejscach, w których specyfika Nilowej interpretacji jest trudna do uchwycenia, zrezygnowaliśmy z poszukiwania analogii u innych autorów. Na pozostałych ponad dwadzieścia pięć miejsc, w więcej niż połowie występują dość wyraźne analogie czy nawet formalne zależności od egzegezy Filona Aleksandryjskiego. Powyższe dane są bardzo umowne, pominęliśmy niektóre zdawkowe aluzje biblijne Nila, niemniej ten wybór daje pewien wgląd $\mathrm{w}$ jego ascetycznie zorientowaną egzegezę. Przedmiotem naszej analizy są właśnie te wypowiedzi, w których natykamy się na zbieżność z wykładnią Filońską. Szukaliśmy styczności raczej pod względem treściowym niż formalnym, jednak wnioski nie będą bez znaczenia dla formalnej zależności Nila od Aleksandryjczyka, której dotychczas nikt gruntownie nie zbadał. Dla uzupełnienia odwołamy się do innych autorów chrześcijańskich, komentujących te same teksty biblijne. Odnośne alegorie przedstawiamy w kolejności występującej w Nilowym piśmie.

1. Palik na ekskrementy (Pwt 23, 14) symbolem wstrzemięźliwości. Nil z Ancyry nawiązuje do Mojżeszowego przepisu na temat higieny w obozie:

„Odganiając zjawiających się, starają się utorować im wygodne przejście, a czynią to dla potrzeby stołu, nie umiejąc pohamować rozkoszy przy łakomym jedzeniu ani nie chcąc nosić palika za pasem dla zakopania nim w razie potrzeby ekskrementów, jak to przepisał Mojżesz. Ci, którzy posługiwali się nim, wiedzieli, że gardło stanowi kres przyjemności jedzenia i że wszystko to,

* Prof. dr hab. Leon Nieścior OMI - kierownik Katedry Teologii Patrystycznej w Instytucie Teologii Systematycznej na Wydziale Teologicznym Uniwersytetu Kard. Stefana Wyszyńskiego w Warszawie; e-mail: 1.niescior@uksw.edu.pl. 
co znajdujemy dla zaspokojenia potrzeby ciała, [jakby] przykrywa bezwstyd niewłaściwej żądzy".

Autor thumaczy dość pomysłowo zakopanie odchodów w ziemi palikiem, które obrazuje zaspokojenie potrzeb elementarnych ciała, co stanowi tamę dla dalszych jego roszczeń.

Ów palik także dla Filona Aleksandryjskiego staje się znakiem wstrzemięźliwości. Zauważa on, że doznania zmysłowe - wzrokowe, słuchowe czy smakowe - odciagają umysł od kontemplacji właściwych jej przedmiotów. Te ostatnie wydają się szkodzić najbardziej. Polecenie, żeby mieć kołek za pasem wychodząc za obóz, wskazuje na potrzebę opanowania umysłu, które niejako „wykopuje rzeczy ukryte”. Należy powściagać rozum, aby nie ulegał namiętnościom, lecz powstrzymywał potrzeby ciała, które nie powinny nim kierować. Ulegając rozkoszy stajemy się jej niewolnikami, natomiast gdy umysł ją opanowuje, niejako ją usuwa. Nie korzystając do syta z jedzenia i picia, praktykuje się umiarkowanie i zachowuje trzeźwą rozwagę ${ }^{2}$. Rozum powinien panować nad namiętnością, którą niejako wygrzebuje z ziemi, podnosi i odsłania ${ }^{3}$.

W duchu alegorycznym wykład na ten temat wygłosił Orygenes, który z poziomu etycznego przeszedł na religijny. Ci, którzy pragną pokonać wrogów duchowych, winni unikać wszelkiego rodzaju nieczystości. Jednak wszyscy upadamy z wielką łatwością, nie zawsze nawet świadomi swoich win (por. Ps 19, 13), skoro mieszka w nas prawo grzechu (por. Rz 17, 23). Te upadki pod wpływem słabości są często nieznane innym, mają miejsce jakby poza obozem. Powinny być wyeliminowane, niejako „pogrzebane” przez skarcenie. Kiedy odstępujemy od złych uczynków, odnawiając się i zwracając ku temu co słuszne, usuwamy ową grzeszną nieczystość niczym odchody i powracamy do „Kościoła pierworodnych” niczym do obozu. Taka przemiana dokonuje się w Chrystusie. Przyjmując Jego krzyż, stajemy się zdeterminowani w odrzucaniu tych grzechów. To właśnie palik za pasem jest symbolem krzyża ${ }^{4}$. Orygenes zdaje się opisywać walkę codzienną chrześcijanina z grzechami powszednimi.

Komentując Pwt 23, 14 w duchu Orygenesowym, także Grzegorz Wielki dostrzega w paliku ostrze naszej skruchy, którą posługujemy się dla skarcenia siebie. Z kolei do odchodów da się porównać zbędne myśli, które wydaje umysł obciążony naturą podatną na zepsucie. Dzięki wnikliwemu roztrząsaniu umysł odrzuca próżne myśli i niejako zakopuje w ziemi przez ból pokuty, i ukrywa

\footnotetext{
${ }^{1}$ Nilus Ancyranus, De monastica exercitatione 8, PG 79, 728, thum. L. Nieścior, w: Nil z Ancyry, Pisma ascetyczne, ŹM 46, Kraków 2008, 72.

${ }^{2}$ Por. Philo Alexandrinus, Legum allegoriarum lib. II 27-28, ed. L. Cohn, w: Philonis Alexandrini opera quae supersunt, ed. L. Cohn - P. Wendland, vol. 1, Berolini 1896, 96, thum. L. Joachimowicz: Filon Aleksandryjski, Alegorie praw, w: Filon Aleksandryjski, Pisma, t. 1, Warszawa 1986, 118.

${ }^{3}$ Por. tamże III 153-154, ed. Cohn, s. 146, tłum. Joachimowicz, s. 169.

${ }^{4}$ Por. Origenes, Adnotationes in Deuteronomium 5, 14, PG 17, 32.
} 
to, co z nas wstrętnego i zbędnego się wydobywa ${ }^{5}$. Te środki „higieny” następują przede wszystkim dla uszanowania świętości miejsca naznaczonego obecnością Boga. Wzgląd świętości Boga przechadzającego się po obozie jest obecny w samym fragmencie biblijnym (por. Pwt 23, 15) oraz u liczniejszych jego komentatorów: poza Orygenesem m.in. u Cyryla Aleksandryjskiego ${ }^{6}$.

2. Alegoria nieczystych rąk (Hi 31, 27; Kpł 11, 27. 42). Nil thumaczy przenośnie dwa przypadki nieodpowiedniego użycia rąk - całowania własnych dłoni i chodzenia na czworakach:

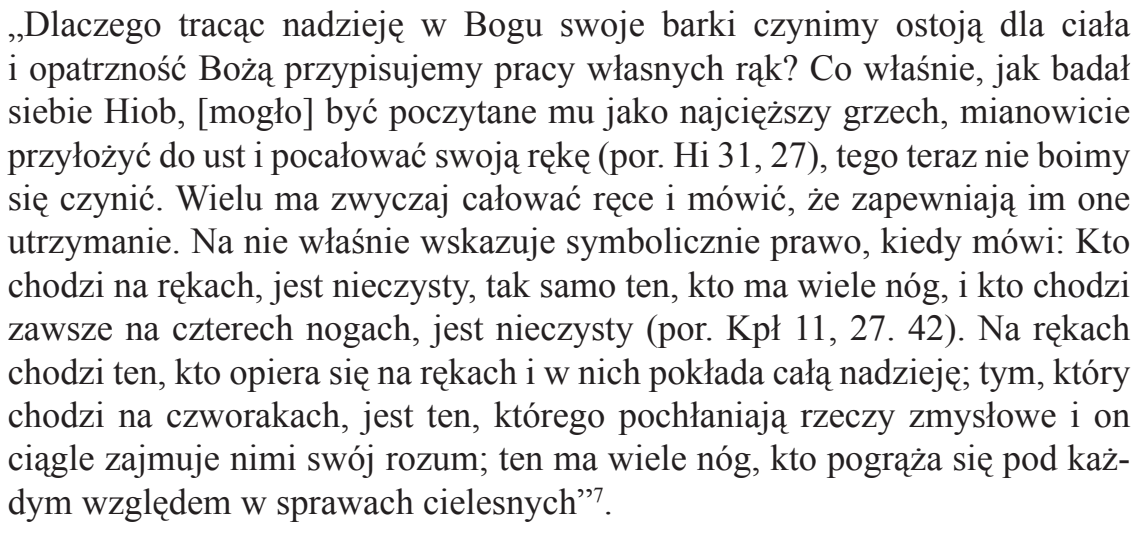

Dwie cnoty zatem nakazywałyby powstrzymać się od wspomnianych gestów czy postaw ciała: pokora i wstrzemięźliwość.

Nie znaleźliśmy komentarza Filona do zakazu całowania swoich rąk. Tymczasem Hieronim zaznacza, że patrząc na słońce, księżyc i gwiazdy, Hiob nigdy nie całował swojej ręki na znak czci składanej bytom stworzonym ${ }^{8}$. Jak stwierdza Platon, u Greków w starożytności istniał zwyczaj prostracji przy wschodzie i zachodzie słońca oraz modlitwy do ciał niebieskich'; później był upowszechniany przez kulty solarne i ubogacany o nowe gesty. Uwaga Hieronima wyraża polemikę z zachowaniem pogańskim. Przyłożenie ręki do ust oznacza dla Grzegorza Wielkiego zgodę pomiędzy czynami i słowami, natomiast jej pocałowanie - chwalenie się dobrymi czynami i przypisywanie ich sobie, podczas gdy wszystko mamy od Boga (por. 1Kor 4, 7$)^{10}$. Dla Orygenesa istnieje podobny, ale dozwolony gest ręki. Mianowicie palec na ustach wskazuje na uznanie

${ }^{5}$ Por. Gregorius Magnus, Moralia in Iob XXXI 54, ed. M. Adriaen, CCL 143B, Turnhout 1985, 1589. W identycznych słowach myśl tę, w pierwszej jej części, przekazuje Izydor z Sewilli (Mysticorum expositiones sacramentorum. In Deuteronomium 21, 1, PL 83, 370).

${ }^{6}$ Por. Cyrillus Alexandrinus, Glaphyra in Pentateuchum, PG 69, 660-661.

${ }^{7}$ Nilus Ancyranus, De monastica exercitatione 14, PG 79, 736, ŹM 46, 79-80.

${ }^{8}$ Por. Hieronymus, Commentarii in Ezechielem III 8, 17, ed. F. Glorie, CCL 75, Turnhout 1964, 102.

${ }^{9}$ Por. Plato, Leges X 887e.

${ }^{10}$ Por. Gregorius Magnus, Moralia in Iob XXII 20, CCL 143A, Turnhout 1979, 1107. 
swego dzieła za mało znaczące i godne milczenia; taki gest powinni uczynić przyjaciele Hioba, aby zamilknąc wobec dokonań i męstwa Hioba ${ }^{11}$.

Mamy z kolei pogląd Filona na temat przepisu Starego Prawa, które uznawało wszystko pełzające na brzuchu i czworonożne za nieczyste. Istoty te są obrazem człowieka miłującego przyjemności. Cztery nogi wyrażają uczucia mające swą podstawę w rozkoszy, a więc, jak dalej stwierdza, namiętności ${ }^{12}$. Pełzające zwierzęta, których nie należy spożywać, symbolizują duszę nie czyniącą postępu, lecz pochłoniętą sprawami ciała, niezdolną do zwrócenia się ku rzeczom niebieskim ${ }^{13}$. Zwierzę czołgające się na brzuchu jest obrazem człowieka idącego np. za przyjemnościami żołądka. Żmija pełza na brzuchu i na piersi: o ile brzuch jest symbolem pożądliwości, to pierś - popędliwości, a więc i gniewu, co także czyni człowieka nieczystym ${ }^{14}$. Taka interpretacja musiała upowszechnić się w egzegezie, skoro dla Jana Damasceńskiego, u schyłku starożytności, nieczyste zwierzę czworonożne podobnie oznaczało człowieka, który pokłada nadzieję w rzeczach zmysłowych i nimi zajmuje swój umysł ${ }^{15}$.

3. Od Lei do Racheli, czyli od latwiejszego do trudniejszego (Rdz 29, 16-28). Nil nawiązuje do postępowania Jakuba, który wziął za żonę Leę, zgodnie z życzeniem teścia Labana, po to, by móc w końcu poślubić Rachelę:

„Jeśli w różnych innych rzeczach, to także i w tym, co dotyczy pobożności, istnieje porządek oraz [pewna] kolejność i należy wprowadzić je w życie od samego początku. Ci, którzy tracą z pola widzenia to, co związane jest z początkiem, i dają się skusić przez coś bardziej atrakcyjnego, w obliczu konieczności zgadzają się na to, by trzymać się kolejności [ustalonego] porządku. Podobnie jak Jakub, który uwiedziony pięknością Racheli, nie zważał na chorobę oczu Lei [i] nie uchylał się przed trudem dzięki osiagnnięciu takiej cnoty, bo spędził u niej tydzień (por. Rdz 29, 27), tak trzeba, aby ten, kto chce w swoim postępowaniu zachowywać słuszny porządek, nie zmierzał od końca do początku, ale podążał od początku do końca"16.

Historia Jakuba staje się alegorią życia duchowego, w którym należy wyznaczać wyższe cele i dążyć do nich z wytrwałością. Do niej wraca Nil w jednym z listów, przestrzegając przed zniechęceniem, acedią, na drodze do cnoty symbolizowanej przez pięknooką Rachelę ${ }^{17}$.

${ }^{11}$ Por. Origenes, Homiliae in Job (fragmenta in catenis, typus II) 5, 9, PG 17, 92; podobnie tenże, Homiliae in Job (fragmenta in catenis, typus I) 29, 9, PG 12, 1041.

${ }^{12}$ Por. Philo Alexandrinus, Legum allegoriarum lib. III 139, ed. Cohn, s. 143, thum. Joachimowicz, s. 166.

${ }^{13}$ Por. tenże, De migratione Abrahami 66, éd. J. Cazeaux, w: Les oeuvres de Philon d'Alexandrie, $\mathrm{N}^{\circ} 14$, Paris 1965, 132.

${ }^{14}$ Por. tamże, éd. Cazeaux, s. 134.

${ }^{15}$ Por. Joannes Damascenus, Sacra parallela, PG 96, 364.

${ }^{16}$ Nilus Ancyranus, De monastica exercitatione 32, PG 79, 761, ŹM 46, 103-104.

${ }^{17}$ Por. tenże, Epistula III 254, PG 79, 509. 
Dla Filona Lea jest symbolem części rozumnej - duszy, Rachela - nierozumnej. Pierwsza każe ubiegać się o dobra duchowe, druga - o rzeczy zewnętrzne: chwałę, zdrowie i przyjemności. Odmienne są skutki obydwu dążeń: zabieganie o pierwsze rodzi sprawiedliwość i pokój, o drugie - namiętności i rozterkę ${ }^{18}$. Nilowa interpretacja różni się w tym miejscu od Filońskiej, gdyż to, co Nil pokazuje jako coś pozytywnego, Filon - jako coś negatywnego. Zgodnie z sensem dosłownym relacji w Rdz 29 Nil nie przeciwstawia sobie dwojakich dążeń wyrażonych obrazem Lei i Racheli, lecz widzi je w pewnej ciagłości. Tymczasem Filon ustawia symboliczne postaci Lei i Racheli w kontraście, który prowadzi ostatecznie do alternatywy między rozsądkiem a lekkomyślnym uleganiem przelotnemu pięknu.

W historii interpretacji owej drogi matrymonialnej Jakuba zdaje się przeważać wykładnia, którą sygnalizuje Nil, już wtedy pewnie upowszechniająca się. Posługuje się nią oględnie Ewagriusz w schemacie trzech etapów drogi duchowej: zwykłej ascezy (,praktyki”), kontemplacji naturalnej („,fizyki”) i kontemplacji nadprzyrodzonej (,teorii”). Uznaje Rachelę za symbol kontemplacji jako finalnego etapu ascezy, podczas gdy Leę - za symbol praktyki ascetycznej ${ }^{19}$. W tym duchu Augustyn również dostrzega w Racheli obraz nadziei na wieczną kontemplację Boga i pełnego rozkoszy poznania prawdy ${ }^{20}$. Grzegorz Wielki stwierdza:

„Rachela bowiem znaczy «widzenie początku» - a Lea - «pracowita». Cóż więc oznacza Rachela, jeśli nie życie kontemplacyjne, cóż Lea, jeśli nie czynne? Poprzez kontemplację szukamy bowiem początku, którym jest Bóg; poprzez aktywność zaś trudzimy się pod ciężkim brzemieniem obowiązków"21.

Wątek ten staje się ulubionym tematem Grzegorza. Taką samą wykładnię stosuje Maksym Wyznawca, werbalnie zależny od Ewagriusza: Lea jest obrazem ascetycznego zmagania się o cnotę, Rachela - „kontemplacji naturalnej” ( $\tau \hat{\eta} \varsigma$



4. Ukryte bożki w Sychem (Rdz 35, 4), czyli namiętności. Nil obszernie komentuje pewien etap wędrówki Jakuba ze swoim domem, który na wezwanie Boga udaje się do Betel (por. Rdz 35). Pod dębem w okolicach Sychem, które wcześniej zdobył (por. Rdz 34, 26; 48, 22), zakopał wszystkie podobizny bożków i kolczyki na uszy, jakie znalazł po drodze u swoich domowników, wypleniając bałwochwalstwo. Autor wykłada przy okazji etymologię „Sychem”,

${ }^{18}$ Por. Philo Alexandrinus, De congressu eruditionis gratia 25-33, ed. P. Wendland, w: Philonis Alexandrini opera quae supersunt, ed. L. Cohn - P. Wendland, vol. 3, Berolini 1898, 77-78.

${ }^{19}$ Por. Evagrius Ponticus, De oratione prol., PG 79, 1165.

${ }^{20}$ Por. Augustinus Hipponensis, Contra Faustum 22, 52, ed. J. Zycha, CSEL 25, Wien 1891, 645.

${ }^{21}$ Gregorius Magnus, Moralia in Iob VI 61, CCL 143, Turnhout 1979, 330, thum. K. Nastał

- L. Gładyszewski - A. Wójcik - E. Buszewicz, ŹM 41, Kraków - Tyniec 2006, 73.

${ }^{22}$ Por. Maximus Confessor, Ambigua ad Joannem 51, 2. 


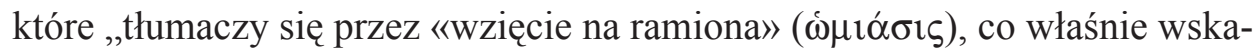
zuje na trud [skierowany] przeciwko namiętnościom"23. Dalej spekuluje nad różnicą między dwoma różnymi sposobami pozbycia się bożków:

„Wydaje się pojawiać pewna sprzeczność pomiędzy tym, by w Sychem za-

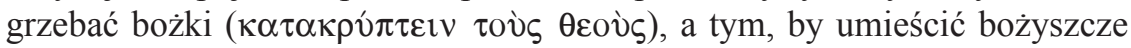

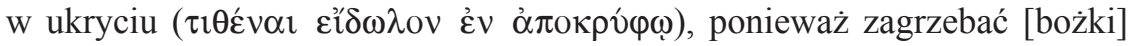
w Sychem jest czymś chwalebnym, a umieścić bożyszcze w ukryciu - nagannym. Tak [Prawo] postanowiło to, obwarowując groźbą przekleństwa, gdy mówi: «Przeklęty ten, kto umieszcza bożyszcze w ukryciu» (Pwt 27, 15). Nie jest tą samą rzeczą zagrzebać [coś] na zawsze w ziemi a umieścić w ukryciu. Przedmiot zagrzebany w ziemi i już nie spostrzegany przez zmysły z czasem umyka też pamięci, podczas gdy przedmiot umieszczony w ukryciu, choć podobnie jest schowany przed postronnymi ludźmi, lecz ciągle pozostaje widoczny dla tego, przez kogo został tam położony, budzi pamięć o sobie, która potajemnie nosi w sobie tę figurkę. Każda bezwstydna myśl, która ukształtowała się w umyśle, stanowi [jakby] ukrytą rzeźbę. Podobnie haniebną rzeczą jest upubliczniać takie myśli, natomiast pozostaje niebezpieczne umieszczać w ukryciu rzeźbę, a jeszcze bardziej niebezpieczne - iść w ślad i poszukiwać wyobrażeń już [raz] wymazanymi [z pamięci], ponieważ umysł łatwo powraca do usuniętej namiętności i na stronę bożków ściąga szalę w dół”24.

Nil dostrzega w przechowywaniu w sobie złej namiętności rodzaj idolatrii. Odrzucenie takiego bałwochwalstwa może być całkowite albo częściowe.

Filon także odwołuje się do postępowania Jakuba, który zakopał pod terebintem w pobliżu Sychem przedmioty związane z kultem bałwochwalczym, należące do jego domowników (por. Rdz 35, 4). Jakub nie przywłaszczył ich,

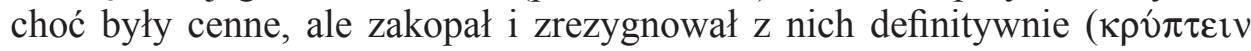

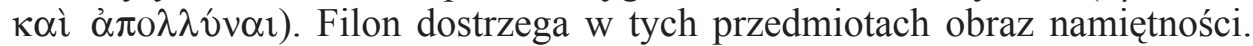
Patriarcha stał się symbolem „mądrego człowieka”, który stłumił i ujarzmił namiętności ${ }^{25}$. Wprawdzie Filon nie roztrząsa subtelnej różnicy między zakopaniem a innym ukrywaniem, ale niewykluczone, że akcentując kategoryczne rozstanie się z bożkami, mógł zainspirować Nila do takich roztrząsań.

Tymczasem słowa z Pwt 27, 15 znalazły zastosowanie monastyczne jeszcze przed Nilem. W nawiązaniu do zakazu przechowywania idolów Ewagriusz widzi podobieństwo między bałwochwalcą i chciwym mnichem, którym wspólne jest to, że ,jeden oddaje cześć bezużytecznemu i zwodniczemu obrazowi, drugi zaś niczym bożka nosi wizję bogactwa"26. Tak samo dla Antiocha

${ }^{23}$ Nilus Ancyranus, De monastica exercitatione 37, PG 79, 765, ŹM 46, 109.

${ }^{24}$ Tamże 38, PG 79, 765. 768, ŹM 46, 109-110.

${ }^{25}$ Por. Philo Alexandrinus, Legum allegoriarum lib. III 22-23, ed. Cohn, s. 118, thum. Joachimowicz, s. 140-141.

${ }^{26}$ Evagrius Ponticus, De octo spiritibus malitiae 8, PG 79, 1153, thum. L. Nieścior: Ewagriusz z Pontu, O ośmiu duchach zła, w: Ewagriusz z Pontu, Pisma ascetyczne, t. 1, ŹM 18, Kraków 2007², 421. 
Mnicha (VII w.) ukrywa bożki mnich, który ulega namiętnej chciwości ${ }^{27}$. Tym bardziej obraz wewnętrznego bałwochwalstwa znajduje zastosowanie w odniesieniu do zagrożeń życia chrześcijańskiego w świecie.

5. Wyjść poza obóz (Wj 33, 7), czyli szukać wyciszenia. Nasz mnich-komentator szuka sensu duchowego w postępowaniu Mojżesza, który rozbił Namiot Spotkania poza obozem Izraelitów podążających do ziemi obiecanej:

„Mojżesz, wziąwszy namiot i założywszy swój namiot poza obozem, daje do zrozumienia, że mistrz powinien trzymać się jak najdalej od wojennego zgiełku i mieszkać daleko od skalanego [krwia] obozu, decydując się na życie spokojne i bez wojny"28.

Autorowi chodzi o coś więcej niż tylko zwykły spokój płynący z przebywania w oddali od skupiska ludzi. W swoich dziełach przedstawia ideał hezychii, wewnętrznego wyciszenia, jako stanu duchowego pokoju, który wynika z przezwyciężenia $\mathrm{w}$ sobie namiętności.

Zdarzenie z Wj 33, 7 kilkakrotnie rozpatruje Filon. Obóz jest polem walki, rywalizacji, wrogości, co ma miejsce za życia w ciele. Duch opuszcza taki obóz, kiedy pod natchnieniem Boga staje w Jego obecności i kontempluje idee. Jak Mojżesz, tak mędrzec przechodzi z wojny, zgiełku i śmierci do pokoju, życia dusz rozumnych i szczęśliwych, nieznających wojny ${ }^{29}$. Wyjście Mojżesza poza obóz oznacza opuszczenie „obozowiska” swego ciała, czyli przekroczenie spraw cielesnych, gdyż tylko w taki sposób można stać się doskonałym w modlitwie wstawienniczej i wielbiącej Boga ${ }^{30}$. Ten czyn wodza Izraelitów oznacza, ,że dusza kochająca Boga zrzuca z siebie ciało i właściwe mu przyjemności i daleko ucieka od nich, a w zamian za to osiaga siłę, stałość i trwałe oparcie w doskonałych naukach cnoty" "31. Rozbijając namiot poza obozem, Mojżesz podejmuje ,niezachwiany sąd”, by w końcu oddać się adoracji Boga i wejść w ciemny obłok, czyli w rzeczywistość niewidzialną, i dostąpić udziału w najświętszych tajemnicach ${ }^{32}$.

6. „Dotain” (Rdz 37, 17), czyli opuszczenie krewnych. W poniższym wywodzie stosuje Nil alegorię wielowarstwową:

\footnotetext{
${ }^{27}$ Por. Antiochus Monachus, Pandecta scripturae sacrae 8, PG 89, 1457.

${ }^{28}$ Nilus Ancyranus, De monastica exercitatione 41, PG 79, 769, ŹM 46, 113; tenże, Epistulae II 64, PG 79, 222.

${ }^{29}$ Por. Philo Alexandrinus, De ebrietate 99-100, éd. J. Gorez, w: Les oeuvres de Philon d'Alexandrie, $\mathrm{N}^{\mathrm{o}}$ 11-12, Paris 1962, 64.

${ }^{30}$ Por. tenże, Quod deterius potiori insidiari soleat160, éd. I. Feuer, w: Les oeuvres de Philon d'Alexandrie, $\mathrm{N}^{\circ}$ 5, Paris 1965, 114-116.

${ }^{31}$ Tenże, Legum allegoriarum lib. II 55, ed. Cohn, s. 101, thum. Joachimowicz, s. 123.

${ }^{32}$ Por. tenże, De gigantibus 54, éd. A. Mosès, w: Les oeuvres de Philon d'Alexandrie, № 7-8, Paris 1963, 46.
} 
„Dlatego może i Józef zabłądził na pustyni, ponieważ w godności [swojego] rodu szukał miary [własnej] doskonałości. $Z$ tego względu również i człowiek, który dla poznania prawdy wypytywał go o przyczynę jego błąkania się, gdy stwierdził, że jest nią przywiązanie do bliskich - gdyby [Józef] nie miał błędnego pojęcia o tym zawodzie, powiedziałby, że bracia pasą trzodę, a nie, że ją karmią ${ }^{33}$ - powiada do niego: «Oni odeszli stąd, ponieważ słyszałem, jak mówili: Chodźmy do Dotain» (Rdz 37, 17). «Dotain» tłumaczy się na «należyte opuszczenie». Pouczył [ów człowiek], że ten, kto kocha to, co cielesne, jeszcze błąka się, i że nie można osiagnąć inaczej doskonałości, jak przez to, że należycie wyzbędzie się przywiązania związanego z fizycznym pokrewieństwem. Jeśli nawet ktoś [...] wyjdzie z doliny Hebronu, [czyli wycofa się] z podłych czynów, i z pustyni, na której zabłądzi ten, kto poszukuje doskonałości, a [jeszcze] nie zdobył się na «należyte opuszczenie» [krewnych], nie będzie miał żadnego pożytku ze swojego długotrwałego mozołu, gdyż przywiązanie do krewnych odwodzi go od doskonałości”"34.

Zdaniem autora nadmierne przywiązanie do rodziny skłoniło Józefa do gorączkowego poszukiwania swych braci. Przy okazji wskazuje na różnicę sen-

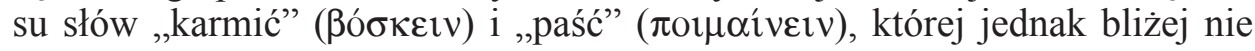
wyjaśnia. Spotkany nieznajomy wskazuje Dotain jako miejsce aktualnego przebywania jego braci, które przez swoją etymologię daje lekcję Józefowi: powinien oduczyć się zbytniego przywiązania do rodziny.

Filon poświęca więcej uwagi Józefowi, który staje się obrazem duszy zdążającej do doskonałości ${ }^{35}$. W jednym z wywodów dokonuje alegorycznej interpretacji odnośnych wydarzeń. Filon też rozróżnia pomiędzy zwykłym żywieniem stada a pasterską troską o nie. Karmić stada oznacza dostarczyć za pokarm rzeczy zmysłowe, nierozumne, które nie mogą nasycić. Takie pożywienie sprawia, że tracimy władzę nad sobą, spożywamy je ze stratą dla duszy. Tymczasem ci, którzy pozostają pasterzami i prawdziwymi przewodnikami stada, przyczyniają się do opanowania czy złagodzenia pragnień zmysłowych. Odejście z Sychem (por. Rdz 37, 13-17) oznacza wędrówkę w kierunku cnoty, opuszczenie przyziemnej rzeczywistości. Józef - uległy przywiązaniu do bliskich, szukający swoich braci na pustyni i błąkający się - jest obrazem duszy, która musi jeszcze przezwyciężyć namiętności, aby posiąść dobra ducho$w^{36}$. Żydowski uczony wyjaśnia etymologię „Dotain”. Miejscowość ta, jego

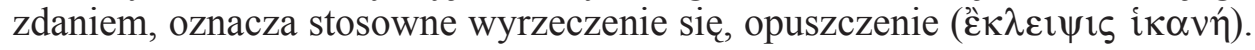

${ }^{33} \mathrm{~W}$ Rdz 37, 16, LXX, Józef pyta o braci, określając ich zajęcie właśnie słowem karmić

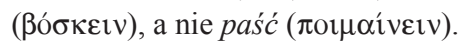

${ }^{34}$ Nilus Ancyranus, De monastica exercitatione 44-45, PG 79, 773. 776, ŹM 46, 117-118; por. tenże, Epistulae II 66, PG 79, 229.

${ }^{35}$ Por. E. Hilgert, The dual image of Joseph in Hebrew and early Jewish literature, „Biblical Research" 30 (1985) 5-21; Th. Tobin, Tradition and interpretation in Philo's portrait of the patriarch Joseph, „Society of Biblical Literature Seminar Papers” 25 (1986) 271-277.

${ }^{36}$ Por. Philo Alexandrinus, Quod deterius potiori insidiari soleat 24-28, éd. Feuer, s. 36-38. 
Symbolizuje duszę, która wyrzekła się nie w sposób połowiczny, ale całkowity, różnych poglądów, namiętności i tego wszystkiego, co szkodzi cnocie ${ }^{37}$. Dokładnie te same alegorie użyte przez Nila i Filona w komentarzu do Rdz 37 wskazują na formalną zależność pierwszego od drugiego, a powyższą wypowiedź Nila wolno uznać za najmocniejszy na to dowód.

Co do etymologii „Dotain”, to staje się dość powszechna. Ambroży także odwołuje się do takiego wyjaśnienia. „Dotain” znaczy „opuszczenie” (defectio). W przenośnej interpretacji nabiera jednak u biskupa Mediolanu innego znaczenia: religijnego, i to w sensie pejoratywnym. Bracia Józefa wyrzekli się, opuścili Boga, chcąc zabić swego brata, co z kolei zapowiada odrzucenie Chrystusa przez Żydów ${ }^{38}$. Tak samo Cyryl Aleksandryjski wykłada etymologię tej miejscowości. Owym „opuszczeniem” jest niedbałość moralna Izraelitów, którzy opuścili się w cnocie, w sprawiedliwości ${ }^{39}$. Werbalnie za taką etymologia, jednak bez szukania sensu alegorycznego, jest także Hieronim, dla którego „Dotain” oznacza „odpowiednie opuszczenie” (sufficiens defectio) ${ }^{40}$.

\section{Dać przekłuć ucho (Wj 21, 6), to zostać niewolnikiem na zawsze.} Nil nawiązuje do wymogu Starego Prawa, by niewolnika hebrajskiego uwolnić w roku szabatowym, po sześciu latach służby, chyba że sam dobrowolnie chciałby dalej przebywać pod władzą pana (por. Wj 21, 2-6):

„Tak samo sługa, który umiłował swego pana, żonę i dzieci, wyrzekając się prawdziwej wolności, ze względu na związek z tym, co cielesne, staje się niewolnikiem na zawsze [i] daje przekłuć ucho szydłem (por. Wj 21,6), aby nie słysząc za pomocą naturalnego organu słuchu, nie przyjął kiedyśs słowa o wolności, lecz pozostawał ciagle niewolnikiem, miłując rzeczy teraźniejsze"41.

Dobrowolna niewola u pana jest dla autora obrazem niewoli moralnej i duchowej.

Tak samo dla Filona niewolnik, który pozwala panu przekłuć ucho na znak swojej dożywotniej niewoli, wyraża niewolę duchową, w której ktoś na skutek braku odpowiedniej formacji ulega uprzedzeniom, namiętnościom, przyjemnościom, niesprawiedliwości, nieroztropności czy fałszywym opiniom. Taki niewolnik, który nie chce być wolny, stanie przed trybunałem Boga, oskarżony o to, że nie chciał słuchać głosu Bożego obwieszczającego wolność jego

${ }^{37}$ Por. tamże 28, éd. Feuer, s. 38; tenże, De fuga et inventione 121-123, éd. E. Starobinski-Safran, w: Les oeuvres de Philon d'Alexandrie, No 17, Paris 1970, 192. 194.

${ }^{38}$ Por. Ambrosius Mediolanensis, De Ioseph 3, 10, ed. C. Schenkl, CSEL 32/2, Wien 1897, 78.

${ }^{39}$ Por. Cyrillus Alexandrinus, Glaphyra in Pentateuchum, PG 69, 304.

${ }^{40}$ Por. Hieronymus, Liber interpretationis hebraicorum nominum „D”, ed. P. de Lagarde, CCL 72, Turnhout 1959, 65. W współcześnie przyjmowanej etymologii słowo to, wzięte z egipskiego „Tutajana”, oznacza „dwie studnie (źródła)”; por. Cz. Bosak, Wszystkie miejsca biblijne. Słownik i konkordancja, t. 1, Kraków 2017, 733.

${ }^{41}$ Nilus Ancyranus, De monastica exercitatione 53, PG 79, 784-785, ŹM 46, 127. 
duszy. To tragiczne, że ten, kto żył pogrążony w świecie rzeczy, nie poznał smaku wolności nawet we śnie ${ }^{42}$.

Dla Efrema Syryjskiego to Chrystus jest owym wyzwolicielem z niewoli. Zgadzamy się dobrowolnie na trwałą służbę Jemu, gdy odrzucamy służbę światu $^{43}$. Dla Ambrożego przekłucie ucha oznacza dotarcie Słowa Bożego do duszy, któremu, rozważając je i praktykując cnotę, zaczyna być posłuszna; w ten sposób, przyjąwszy duchowe tajemnice, zaczyna się uświęcać ${ }^{44}$.

\section{Oglądanie się wstecz żony Lota ( $\operatorname{Rdz} 19,26)$, czyli powrót do na-} miętności. Nil dostrzega alegorię w zachowaniu żony Lota, która uciekając z Sodomy przed kataklizmem nie posłuchała ostrzeżenia aniołów i obejrzała się do tyłu:

„Nie przynosi zatem żadnego pożytku wyrzeczenie się tych rzeczy, jeśli nie będzie się trwało w swoim przekonaniu, ale ponownie da się pociagnąć [przez nie] i ulegnie się myśli [o nich], i dlatego będzie się ciaggle wracać do tego, co się porzuciło, i zdradzać tym samym przywiązanie do nich, jak żona Lota. Ona oglądając się do tyłu stanęła, zamieniona w słup soli, służąc do dziś jako przykład dla nieposłusznych" 45 .

Owa kobieta wyraża zachowanie ludzi, którzy raz podjąwszy decyzję o rezygnacji z czegoś dla wyższych celów, potem, na skutek nadmiernego przywiązania, znowu wracają do tego, czego się wyrzekli.

Podobną metaforykę dostrzega Filon. Gdy ktoś oddalił się od drogi prowadzącej do cnoty, to zmysły, niczym małżonka Lota, będą chciały jeszcze bardziej odwieść od tej drogi i powstrzymać przed dalszym pójściem. Taki człowiek, podobnie jak tamta niewiasta, zostaje niejako zamieniony w słup. Zamiast spoglądać naprzód i kontemplować cnotę oraz czyny cnotliwe, ogląda się w tył, za bogactwem, sława, siłą fizyczna, pięknem ciała, które czynią go „słupem”, czyli człowiekiem bez duszy ${ }^{46}$. Ze względu na nieposłuszeństwo, żona Lota wyraża postawę tego, kto nie słucha swego mistrza. Mając przed sobą takie środki jak wzrok, słuch czy inne zdolności do osądzania spraw natury, „odwraca się do tyłu”, czyli zajmuje się mrocznymi sprawami tego życia i staje się niejako ślepy, głuchy i nierozumny ${ }^{47}$.

${ }^{42}$ Por. Philo Alexandrinus, De cherubim 72-74, éd. J. Gorez, w: Les oeuvres de Philon d'Alexandrie, $\mathrm{N}^{\circ} 3$, Paris 1963, 54.

${ }^{43}$ Por. Ephraem Syrus, Capita centum. Quomodo quis humilitatem sibi comparet 23, ed.

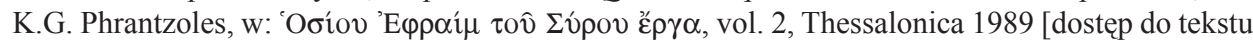
$\mathrm{z}$ bazy Thesaurus Linguae Graecae. A Digital Library of Greek Literature].

${ }^{44}$ Por. Ambrosius Mediolanensis, Expositio psalmi CXVIII 13, 6, ed. M. Petschenig, CSEL 62, Wien 1913, 285.

${ }^{45}$ Nilus Ancyranus, De monastica exercitatione 53, PG 79, 785, ŹM 46, 127-128.

${ }^{46}$ Por. Philo Alexandrinus, De somniis I 246- 248 éd. P. Savinel, w: Les oeuvres de Philon d'Alexandrie, $\mathrm{N}^{\circ} 19$, Paris 1962, 124-126.

${ }^{47}$ Por. tenże, De fuga et inventione 121-123, éd. Starobinski-Safran, s. 192. 194. 
W takiej wykładni mamy szczególnie bogatą reprezentację Szkoły Aleksandryjskiej. Zdaniem Klemensa Aleksandryjskiego, nie naśladować żony Lota, która obejrzała się za siebie, przed czym i Jezus przestrzegał swoich uczniów (por. Łk 17, 31), to nie powracać „do życia poprzedniego, nastawionego wyłącznie na przedmioty postrzegane, ani nie powracać do herezji”"48. Dla Orygenesa, oglądająca się wstecz żona Lota jest obrazem ciała oddanego żądzom i przyjemnościom ${ }^{49}$. Ten sens przejmuje też Ambroży, pilny czytelnik Orygenesa. Owa kobieta uległa temu, co niższe, mianowicie zmysłowości ${ }^{50}$. Jeśli nawet miała czyste spojrzenie, to jednak skalała się: spoglądając wstecz, zważając na nieopanowanie czy rozwiązłość Sodomitów, zwróciła wzrok w gruncie rzeczy ku szatanowi ${ }^{51}$. Przeciwną postawę zachowuje Paweł Apostoł: zapominając o tym, co za nim, a wytężając siły ku temu, co przed nim, pędząc „ku wyznaczonej mecie” (por. Flp 3, 13-14) ${ }^{52}$.

9. Siedzieć na bożkach (Rdz 31, 35), czyli ulegać namiętnościom. Nil doszukuje się przenośni w zachowaniu Racheli, która po kradzieży posążków rodzinnych, podczas przeszukiwania przez Labana obozu Jakuba, ukryła je pod sobą:

„Popatrz na duszę, która idzie za swoimi nawykami, jak ona «siedzi na bożkach», przytwierdzając się do materii bez kształtu, i wzbrania się przed przyjęciem nauki, która mogłaby zaprowadzić ją do rzeczy wyższych, mówiąc: «Nie mogę podnieść się w twojej obecności, ponieważ mam kobiecą przypadłość» (Rdz 31, 35). Dusza, która od dawna zanurzyła się w ziemskich rzeczach, prawdziwie «siedzi na bożkach», to jest na przedmiotach, które nie mają formy w sobie samych, a otrzymują formę przez ludzką sztukę. Bogactwo, chwała i inne rzeczy ziemskie są rzeczami bez kształtu, nie mając [w sobie] niczego określonego ani czegoś, w czym można wyróżnić jakieś członki. Przez złudne podobieństwo zadają kłam prawdzie, zmieniają się codziennie z jednej rzeczy w drugą. To my nadajemy im kształt, kiedy tym rzeczom, które nie przydają się do niczego użytecznego, nadajemy użyteczność wymyśloną ludzkim rozumowaniem"53.

${ }^{48}$ Clemens Alexandrinus, Stromata VII 93, 4, ed. O. Stählin - L. Früchtel - U. Treu, GCS 17, Berlin 1970², 66, thum. J. Niemirska-Pliszczyńska: Klemens Aleksandryjski, Kobierce zapisków filozoficznych dotyczacych prawdziwej gnozy, t. 2, Warszawa 1994, 295.

${ }^{49}$ Por. Origenes sec. translationem Rufini, In Genesim homiliae 5, 5, ed. W.A. Baerhens, GCS 29, Leipzig 1920, 64.

${ }^{50}$ Por. Ambrosius Mediolanensis, De fuga saeculi 1, 2, ed. C. Schenk1, CSEL 32/2, Wien 1897, 164.

${ }^{51}$ Por. tenże, Explanatio psalmorum XII 43, 34, 1, ed. M. Petschenig, CSEL 64, Wien 1919, 286; tenże, Expositio evangelii secundum Lucam VIII 45 (in 17, 32), ed. M. Adriaen, CCL 14, Turnhout 1957, 313; tenże, De virginibus II 4, 29, ed. F. Gori, Biblioteca Ambrosiana 14/1, Milano - Roma 1989, 190.

${ }^{52}$ Por. tenże, De fuga saeculi 1, 2, CSEL 32/2, 164.

${ }^{53}$ Nilus Ancyranus, De monastica exercitatione 54, PG 79, 785, ŹM 46, 128-130. 
Pod wpływem namiętności człowiek nabywa złudnych wyobrażeń o dobrach doczesnych, do których usilnie dąży. Stają się one niczym bóstwa, e’’ $\delta \omega \lambda \alpha$, w jego wnętrzu.

Podobnie dla Filona Aleksandryjskiego, Rachela siedząca na posążkach

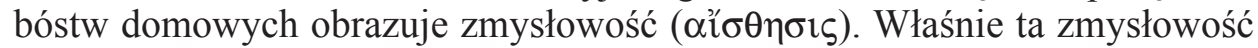
skłania ją do żądania od męża, Jakuba, potomstwa (por. Rdz 30, 1). Rachela sądzi, że te pragnienia pochodzą z umysłu, podczas gdy pochodzą z jej zmysłowości. Jakub tłumaczy, że to nie do niego ostatecznie należy dać potomstwo, lecz do Boga ${ }^{54}$. Co do zmysłowego nastawienia Racheli, to w nawiązaniu do Rdz 31, 35 Filon w innym miejscu wymienia te same dobra ziemskie upragnione przez córkę Labana, które wylicza i Nil, a mianowicie „chwałę, bogactwo i temu podobne rzeczy", dodając ponadto ,piękno cielesne" 55 .

Grzegorz Wielki dostrzega tymczasem w siedzeniu Racheli na posążkach coś pozytywnego. Żona Jakuba jest obrazem Kościoła, który przez pokorę pokuty niejako przykrywa grzechy i wady wynikające z ziemskiego pożądania. Rachela symbolizuje w gruncie rzeczy każdego chrześcijanina, który przez pokutę usuwa winę chciwości ${ }^{56}$.

10. Czolgać się (Rdz 3, 14), to ulegać nieczystości i gniewowi. W pełzającej postawie węża, którego Bóg przeklina w raju, Nil dopatruje się następującej alegorii:

„Także ten, który czołga się «na piersi i brzuchu» (Rdz 3, 14), kiedy dysponuje materią dostarczającą przyjemności, czołga się na brzuchu, kiedy zaś jej brakuje, pełza na piersi, skąd [pochodzi] gniew, dlatego że ci, którzy mają upodobanie w przyjemnościach, kiedy są ich pozbawieni, gniewają się i ulegają rozgoryczeniu" 57 .

Pierś obrazuje „część gniewliwą” duszy, a brzuch - „część pożądliwą”. Pełzać na tych częściach ciała oznacza ulegać odnośnym namiętnościom.

Filon także odwołuje się do Rdz 3, 14. Właśnie „,w tych częściach, w piersi i brzuchu, ukrywają się namiętności" ${ }^{58}$. Zgodnie z antyczną tradycją umiejscawia pożądliwość $\mathrm{w}$ brzuchu i jego okolicach, natomiast popędliwość, a więc gniewliwość, w piersi. Przywołuje klasyczny platoński trójpodział duszy na części rozumna, popędliwą i gniewliwą ${ }^{59}$. Tak samo w zakazie spożywania

${ }^{54}$ Por. Philo Alexandrinus, Legum allegoriarum lib. II 46, ed. Cohn, s. 99, thum. Joachimowicz, s. 121.

${ }^{55}$ Por. tenże, De ebrietate 52-54, éd. Gorez, s. 44.

${ }^{56}$ Por. Gregorius Magnus, Moralia in Iob XXX 72, CCL 143B, 1539; to samo w: Isidorus Hispalensis, Mysticorum expositiones sacramentorum. In Genesim 26, 24, PL 83, 265.

${ }^{57}$ Nilus Ancyranus, De monastica exercitatione 55, PG 79, 788, ŹM 46, 130.

${ }_{58}$ Philo Alexandrinus, Legum allegoriarum lib. III 114, ed. Cohn, s. 138, thum. Joachimowicz, s. 160.

${ }^{59}$ Por. tamże III 114-119, ed. Cohn, s. 138-139, thum. Joachimowicz, s. 160-161; tenże, De migratione Abrahami 64-66, éd. Cazeaux, s. 132. 134. Na temat antropologii Filona zob. D. Win- 
zwierząt pełzających i pewnego rodzaju zwierząt czworonożnych (por. Kpł 11, 42) Aleksandryjczyk dostrzega alegorię: „Tego rodzaju stworzeniem jest miłośnik rozkoszy, który idzie zawsze za brzuchem i jego przyjemnościami" ${ }^{60}$. Wstrętna jest taka dusza, która nie poświęca części samej siebie na to, aby kroczyć, ale, pochłonięta przez rzeczy cielesne, traci zdolność patrzenia w niebo ${ }^{61}$.

Powyższą przenośnię stosują też pisarze starochrześcijańscy. Dla Ambrożego zwierzęta pełzające są także obrazem ludzi przyziemnych, którzy myślą o rzeczach niższych, nie zwracając spojrzenia ku niebu ${ }^{62}$. Podobnie dla Anastazego Synajskiego ludzie zmysłowi są podobni do zwierząt pełzających, którzy koncentrują się na potrzebach brzucha i jego okolic, nie mając w sobie boskiego tchnienia ${ }^{63}$. Ulegają namiętnościom, ziemskim przyjemnościom i myślom ${ }^{64}$.

11. Pektoral (Wj 28, 4) symbolem rozumu. Nil zajmuje się symboliką pektorału ( $\tau$ ò $\lambda o ́ \gamma$ iov) jako części ubioru kapłańskiego, ustalonego przez Mojżesza. Był nią napierśnik ze słowem wyroczni.

„Dlatego wielki Mojżesz nakazał zawiesić na piersi kapłana pektorał (por. Wj 28,4 ), wskazując przez ten symbol, że trzeba rozważnie hamować porywy namiętności gniewu dzięki rozsądkowi. Pektorał oznacza sferę rozumną; i ów [kapłan] rozumem opanowuje namiętność, [gdyż] jest niedoskonały, tymczasem doskonały Mojżesz całkowicie uśmierza gniewliwość, ponieważ nie nosi słowa wyroczni, ale odcina samą pierś. Jest powiedziane: «Biorąc pierś ofiarował ją przed Panem» $(\mathrm{Kpł} \mathrm{8,} \mathrm{29)"'65.}$

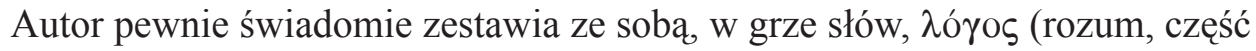
rozumną duszy) i $\lambda$ ó

$\mathrm{Z}$ kolei w pektorale zawieszonym na piersi Aarona przed wejściem do miejsca świętego (por. Kpł 28, 30), Filon dostrzega symbol organu mowy. Pektorał wyraża jednak mowę przemyślaną i roztropną ${ }^{66}$. Nałożenie napierśnika oznacza poddanie władzy rozumu części popędliwej, co znajduje wyraz

ston, Philo of Alexandria on rational and irrational emotions, w: Passions and moral progress in Greco-Roman thought, ed. J.T. Fitzgerald, New York - London 2008, 201-220; G.H. van Kooten, The anthropological trichotomy of spirit, soul and body in Philo of Alexandria and Paul of Tarsus, w: Anthropology in the New Testament and its ancient context, ed. M. Labahn - O. Lehtipuu, Leuven 2010, 87-119; L. Kerns, Soul and passions in Philo of Alexandria, StPatr 63 (2013) 141-154.

${ }^{60}$ Philo Alexandrinus, Legum allegoriarum lib. III 139, ed. Cohn, s. 143, thum. Joachimowicz, s. 166; por. tamże, III 160, ed. Cohn, s. 147, thum. Joachimowicz, s. 170.

${ }^{61}$ Por. tenże, De migratione Abrahami 64, éd. Cazeaux, s. 132.

${ }^{62}$ Por. Ambrosius Mediolanensis, De paradiso 15, 74, ed. C. Schenkl, CSEL 32/1, Wien 1897, 333.

${ }^{63}$ Por. Anastasius Sinaiticus, In Hexaemeron I 7, 2, ed. J.D. Baggarly - C.A Kuehn, Anastasius of Sinai Hexaemeron, OCA 278, Rome 2007, 24.

${ }^{64}$ Por. tamże XI 4, 6, ed. Baggarly - Kuehn, s. 414.

${ }^{65}$ Nilus Ancyranus, De monastica exercitatione 56, PG 79, 788-789, ŹM 46, 130.

${ }^{66}$ Por. Philo Alexandrinus, Legum allegoriarum lib. III 118-119, ed. Cohn, s. 139, thum. Joachimowicz, s. 161. 
w odpowiednim słowie prawdy wypowiedzianym z rozeznaniem i jasnością ${ }^{67}$. Odcięcie przez Aarona piersi ofiary sakralnej oznacza tymczasem poskromienie części gniewliwej ${ }^{68}$.

W jednej z konferencji Doroteusz z Gazy, zapewne za innymi, wyjaśnia alegorycznie przepisaną przez Mojżesza ofiarę z różnych elementów wnętrzności zwierzęcych. Odwołuje się przy tym do tradycyjnego trójpodziału duszy. Podobnie jak ofiara ze zwierzęcia, tak dusza ma być we wszystkich swoich częściach ofiarowana Bogu. „Władzy gniewliwej zaś symbolem jest serce. Ono jest uważane za siedlisko gniewu, na co wskazuje św. Bazyli mówiąc, że gniew to wrzenie i ruch krwi wokoło serca"69. Pierś z kolei, a zwłaszcza żebro, wyraża władzę poznawczą. Zawieszony na piersi pektorał, w który ubierał Mojżesz Aarona, ma podobną symbolikę. Każda część duszy ma swój cel. Celem władzy poznawczej jest „oglądanie prawdy" ${ }^{\prime 70}$. W swojej interpretacji Doroteusz odwołuje się do Ewagriusza. W zachowanym w dwóch wersjach syryjskich piśmie mnicha pontyjskiego pektorał podobnie wyraża wiedzę o tajemnicach Bożych ${ }^{71}$.

\section{Obmycie cielca ofiarnego $(\mathrm{Kpl} 9,14)$ symbolem oczyszczenia czlo-} wieka. Kolejna spekulacja Nilowa dotyczy obmycia cielęcia zabitego na ofiarę przebłagalną, czego dokonywał Aaron na polecenie Mojżesza. Autor przypisuje tę ofiarę całopalną Mojżeszowi:

„I tutaj istnieje różnica pomiędzy doskonalącym się a doskonałym. Mojżesz, który odrzucił w sposób doskonały przyjemność pokarmów, «obmył wnętrzności i nogi wodą» (Kpł 9, 14), przez wnętrzności wskazując na przyjemność, a przez nogi - na wstępowanie i postęp. Ten, kto postępuje, obmywa to, co we wnętrznościach, a nie całe wnętrzności. Zachodzi wielka różnica pomiędzy tym, że [Mojżesz] «obmył», a tym, że [inni] «obmyją», ponieważ pierwsze zostaje uczynione dobrowolnie, a drugie $-\mathrm{z}$ nakazu" ${ }^{\prime 2}$.

Dla pisarza każdy szczegół ma swoje znaczenie: obmycie wnętrzności oznacza ascezę związaną z pokarmami, nóg - postęp duchowy; wypłukanie jelit - ascezę

${ }^{67}$ Por. tamże III 124, ed. Cohn, s. 140, thum. Joachimowicz, s. 162-163.

${ }^{68}$ Por. tamże III 128-129, ed. Cohn, s. 141, thum. Joachimowicz, s. 163-164. Na temat symboliki szat kapłańskich zob. J. Laporte, The high priest in Philo of Alexandria, „The Studia Philonica Annual” 3 (1991) 71-82; M.N. Fernández, Rewritten Bible or imitatio?: the vestments of the high-priest, w: Studies in the Hebrew Bible, Qumran, and the Septuagint presented to E. Ulrich, ed. W. Flint - E. Tov - J.C. VanderKam, Boston 2006, 321-336.

${ }^{69}$ Dorotheus Gazaeus, Doctrinae diversae XVII 176, ed. L. Regnault - J. de Préville, SCh 92, Paris 1963, 480, thum. M. Borkowska: Doroteusz, Nauki, w: Doroteusz z Gazy, Pisma ascetyczne, ŹM 51, Kraków 2010, 246; Basilius Magnus, Commentarius in Isaiam 5, 25, PG 30, 424.

${ }^{70}$ Por. Dorotheus Gazaeus, Doctrinae diversae XVII 176, SCh 92, 480, ŹM 51, 247.

${ }^{71}$ Por. Evagrius Ponticus, Kephalaia gnostica IV 66, ed. A. Guillaumont: Les six Centuries des 'Képhalaia gnostica'd'Évagre le Pontique. Édition critique de la version syriaque commune et édition d'une nouvelle version syriaque, intégrale, avec une double traduction française, Paris 1958, 165-166.

${ }^{72}$ Nilus Ancyranus, De monastica exercitatione 56, PG 79, 789, ŹM 46, 131. 
na etapie doskonalenia się, obmycie całych wnętrzności - doskonałość; obmycie przez Mojżesza - czynność dobrowolna, przez innych - nakazaną.

Filon poświęca więcej uwagi powyższemu aktowi rytualnemu. Również i on przypisuje ten akt Mojżeszowi, który obmył brzuch oraz nogi ofiary przeznaczonej na całopalenie (por. Kpł 9, 14). W nim mieści się niejako konsekracja całej duszy, która jest godna ofiarowania się Bogu. Obmycie całego brzucha wyraża oczyszczenie się z przyjemności związanych z tą częścią ciała oraz podbrzuszem. W akcie ofiary jest się gotowym do abstynencji nawet od koniecznego pożywienia i napoju, żywiąc się kontemplacją rzeczy boskich. Nogi symbolizują podstawę rozkoszy, a podstawą rozkoszy są rzeczy wywołujące podnietę. Filon nie mówi tego wyraźnie, ale zdaje się wskazywać na następującą symbolikę: ograniczając przyjemne doznania zmysłowe asceta rezygnuje nie tylko z doznań, ale stara się również ograniczyć ich przyczyny tkwiące w rzeczach zewnętrznych, takich, jak choćby pokarmy. Aleksandryjczyk wprowadza rozróżnienie pomiędzy doskonałym a dopiero dążącym do doskonałości: ten pierwszy obmywa cały brzuch, podczas gdy drugi obmywa tylko wnętrzności (i jak tamten - nogi) (por. Kpł 1, 9). Nie jest bowiem w stanie usunąc każdej rozkoszy zmysłowej i poprzestaje na rezygnacji z bardziej wyrafinowanych przyjemności, na przykład jedzenia wyszukanych potraw. Zatem nie wyrzeka się wszystkich przyjemności, ale praktykuje w nich umiarkowanie. Filon rozróżnia pomiędzy działaniem $\mathrm{z}$ własnej woli i na rozkaz. Człowiek doskonały wyrzeka się przyjemności sam z siebie, z własnej chęci, bez rozkazu, podczas gdy dążący do doskonałości czyni to pod wpływem imperatywu płynącego z rozumu, który poucza o tym, co należy czynić. Filon podobnie jak Nil spekuluje nad różnicą użytych trybów: oznajmującego w Kpł 9, 14 i rozkazującego w Kpł 1, 13 ${ }^{73}$. Zależność Nila od Filona jest ewidentna. Komentarz Nilowy, będąc streszczeniem komentarza Filońskiego, staje się w pełni zrozumiały dopiero po lekturze tego drugiego.

13. Kuchmistrz babiloński $(\mathrm{Jr} 52,14)$ symbolem obżarstwa. Autor De monachorum exercitatione" szuka alegorii w osobie Nebuzaradana, który przyczynił się do zdobycia Jerozolimy przez Nabuchodonozora, króla babilońskiego:

\footnotetext{
${ }^{73}$ Por. Philo Alexandrinus, Legum allegoriarum lib. III 141-144, ed. Cohn, s. 144, thum. Joachimowicz, s. 166-167. Pobyt w diasporze Aleksandryjskiej z pewnością sprzyjał spirytualizacji ofiar nakazanych przez Prawo Mojżeszowe. Por. J. Laporte, Sacrifice in Origen in the light of Philonic models, w: Origen of Alexandria: his world and his legacy, ed. Ch. Kannengiesser - W. L. Petersen, Notre Dame (Ind.) 1988, 250-276; tenże, Sacrifice and forgiveness in Philo of Alexandria, „The Studia Philonica Annual" 1 (1989) 34-42; F. Calabi, Les sacrifices et leur signification symbolique chez Philon d'Alexandrie, w: "Car c'est l'amour qui me plaît, non le sacrifice...»: recherches sur Osée 6:6 et son interprétation juive et chrétienne, éd. E. Bons, Leiden - Boston 2004, 97-117; A. Lieber, Between motherland and fatherland: diaspora, pilgrimage and the spiritualization of sacrifice in Philo of Alexandria, w: Heavenly tablets: interpretation, identity and tradition in ancient Judaism, ed. A. Lieber, Leiden - Boston 2007, 193-210; P.M. Robertson, Toward an understanding of Philo's and Cicero's treatment of sacrifice, „The Studia Philonica Annual” 23 (2011) 41-67.
} 
„To wyraził zagadkowo Jeremiasz, kiedy powiedział, że kuchmistrz Babilończyków zburzył mur wokół Jerozolimy (por. 2Krl 25, 8-10; Jr 52, 1415), przez kuchmistrza rozumiejąc namiętność obżarstwa. Jak kuchmistrz dokłada wszelkiej troski, żeby dogodzić żołądkowi, i wymyśla tysiące sztuczek, żeby dostarczyć przyjemności, tak i obżarstwo dopuszcza się wszelkiego podstępu i służy przyjemności zwalczając głód, gdy tymczasem rozmaitość pokarmów niszczy i unicestwia moc cnót niczym warowność muru"74.

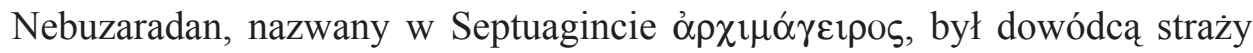
przybocznej na dworze Nabuchodonozora, a więc wysokim oficerem wojskowym. Tak samo został nazwany w Biblii greckiej urzędnik faraona, Potifar

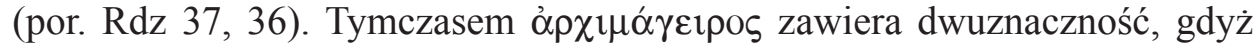
może oznaczać także szefa kuchni czy pewną godność religijną w kręgu czcicieli Mitry. Jak widzimy, Nil rozumie tę funkcję w sensie zwierzchnika kucharzy.

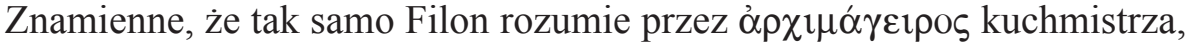
aczkolwiek nie odnosi się do Nebuzaradana, ale właśnie Potifara: Józef zostaje sprzedany w niewolę eunuchowi, który jest kucharzem faraona, stając się symbolem duszy jałowej, niepłodnej, podobnej raczej do mężczyzny niż kobiety, uległej przyjemnościom spożywania wyszukanych pokarmów i picia napojów ${ }^{75}$.

Pewnie można mówić o tradycji aleksandryjskiej powyższej interpretacji, skoro także Orygenes do niej się odwołuje. Jerozolima jest symbolem poznania i cnoty oraz Kościoła, Nabuchodonozor - diabła, a kuchmistrz, który przyczynił się do zdobycia miasta - życia niewstrzemięźliwego. Znaczenie całego obrazu jest takie: kto oddaje się życiu nieopanowanemu, idzie w niewolę grzechu i zła ${ }^{76}$. Powyższa alegoria staje się nośna, gdyż swój ślad zostawiła także w sentencjach Ojców Pustyni, a dokładnie w apoftegmacie przypisywanym abba Pojmenowi: „Gdyby Nebuzaradan, przełożony kucharzy, nie nadciagnął, świątynia Pańska nie zostałaby zburzona. A to znaczy: gdyby dusza nie szukała rozkoszy w obżarstwie, nie upadłaby w walce z nieprzyjacielem" 77 . Narzuca się następująca interpretacja: świątynią zburzoną jest dusza, która ulega namiętnościom i przegrywa ze Złym.

Tak oto w naszej rekonstrukcji wyłania się pewien łańcuch biblijnej interpretacji, która znajduje swoje ascetyczne zastosowanie: Filon - Orygenes - mnisi egipscy - Nil z Ancyry. Jeśli przyjmiemy, idąc za biograficzną wzmianką samego Nila, że za młodu przebywał jakiś czas w Aleksandrii i zaprawiał

${ }^{74}$ Nilus Ancyranus, De monastica exercitatione 58, PG 79, 792, ŹM 46, 133-134; por. tenże, Epistulae II 107, PG 79, 248.

${ }^{75}$ Por. Philo Alexandrinus, De ebrietate 210-211, éd. Gorez, s. 108-110; podobne aluzje do Potifara występują też w innych dziełach Filona.

${ }^{76}$ Por. Origenes, Selecta in Ezechielem 17, 12, PG 13, 813.

${ }^{77}$ Apophthegmata patrum (collectio alphabetica), Poemen 16, PG 65, 325, thum. M. Borkowska: Apoftegmaty Ojców Pustyni, t. 1: Gerontikon, ŹM 4, Kraków 1994, 392. 
się do życia ascetycznego pod pieczą pewnego starca ${ }^{78}$, to wszystkie ogniwa w tym łańcuchu stają się jeszcze bardziej zrozumiałe.

Podsumowując stwierdzamy, że w De monastica exercitatione znajduje się co najmniej kilkanaście przypadków interpretacji alegorycznej tekstów Starego Testamentu, w których egzegeza Nila z Ancyry wydaje się nawiązywać do wykładni Filona Aleksandryjskiego. W kilku miejscach zachodzą spore różnice interpretacyjne, w zdecydowanej jednak mierze Nil kontynuuje czy powtarza myśl egzegetyczną Filona. W dwóch przypadkach, w dłuższym wykładzie alegorii na temat Józefa poszukującego swoich braci oraz rytualnego obmycia cielca (rozdziały 44-45 i 56), zależność od Filona staje się werbalna. Zapożyczenia pochodzą najczęściej z Legum allegoriarum libri, które pewnie były dla Nila szczególnie bliską lekturą. Jednak ślady Filońskiej egzegezy pochodzące z innych pism Aleksandryjczyka, każą zakładać szerszą znajomość jego dzieł. Owszem, możliwe były pośrednie zapożyczenia i pośrednia znajomość egzegezy Filońskiej przez Nila, poprzez innych autorów, niemniej nie znajdujemy na to dowodów. Na przykład związki Orygenesa z Filonem w egzegezie rozpatrywanych miejsc są dość luźne i nie dają podstaw do szukania w nim takiego pośrednictwa. Ascetyczna orientacja egzegezy Filona, jego spokrewnienie z filozofią grecką na gruncie etycznym, chętne posługiwanie się alegorią biblijna, te i inne czynniki zadecydowały być może o inspirowaniu się przez Nila filozofem żydowskim. Powyższe zapożyczenia miały też swoje konsekwencje. Kopiowanie Filońskiej myśli prowadziło też do przejmowania idei przejętych przez niego od innych, a m.in. elementów platonizmu i stoicyzmu.

\section{TRACES OF PHILO OF ALEXANDRIA'S EXEGESIS IN NIL OF ANCYRA'S DE MONASTICA EXERCITATIONE}

\section{(Summary)}

We encounter in the Nil of Ancyra's writing De monastica exercitatione at least a dozen instances of the allegorical interpretation of certain places in the Old Testament, where Nil of Ancyra's exegesis seems to refer to the Philo of Alexandria's interpretation. In a few places there are significant differences in interpretation, but Nil decisively continues or repeats exegetical ideas of Philo. In two cases, in a longer allegory about Joseph who seeks his brothers and about the ritual washing of the sacrificial calf (De monastica exercitatione 44-45 and 56), the dependence on Philo becomes verbal. The borrowings come most often from

${ }^{78}$ Por. Nilus Ancyranus, De vita monastica 1, ed. P. Bettiolo, w: Gli scritti siriaci di Nilo il Solitario, Leuven 1983, 75. 
Legum allegoriarum libri, which seem to be especially close to Nil. However, the traces of Philo's exegesis from other writings of the Alexandrian seem to show a wider knowledge of his works by the monk of Ancyra. There is a probability of indirect borrowing and indirect knowledge of Philo's exegesis by Nil, by other authors, but we find no evidence of such medium. However, for example, Origen's relationship with Philo in the exegesis of the concerned places is quite loose and does not give grounds for the seeking such medium. The Philo's ascetic orientation to exegesis, his connection to Greek ethical philosophy, willingness to use the biblical allegory, these and other factors may have influenced Nil to seek inspiration by the Jewish philosopher. The predicted borrowings had also their consequences. The copying Philonian thought led to take over the ideas borrowed by others, including the elements of Platonism and Stoicism.

Key words: Nil of Ancyra, De monastica exercitatione, Philo of Alexandria, allegorical exegesis, ancient monasticism.

Slowa kluczowe: Nil z Ancyry, De monastica exercitatione, Filon Aleksandryjski, egzegeza alegoryczna, monastycyzm starożytny.

\section{BIBLIOGRAFIA}

\section{Źródła}

Ambrosius Mediolanensis, De fuga saeculi, ed. C. Schenkl, CSEL 32/2, Wien 1897 , 163-207.

Ambrosius Mediolanensis, De Ioseph, ed. C. Schenkl, CSEL 32/2, Wien 1897, 73-122.

Ambrosius Mediolanensis, De paradiso, ed. C. Schenkl, CSEL 32/1, Wien 1897, 263-336.

Ambrosius Mediolanensis, De virginibus, ed. F. Gori, Biblioteca Ambrosiana 14/1, Milano - Roma 1989, 10-240.

Ambrosius Mediolanensis, Explanatio psalmorum XII, ed. M. Petschenig, CSEL 64, Wien 1919.

Ambrosius Mediolanensis, Expositio evangelii secundum Lucam, ed. M. Adriaen, CCL 14, Turnhout 1957, 1-400.

Ambrosius Mediolanensis, Expositio psalmi CXVIII, ed. M. Petschenig, CSEL 62, Wien 1913.

Anastasius Sinaiticus, In Hexaemeron anagogicarum contemplationum libros duodecim, ed. J.D. Baggarly - C.A Kuehn, Anastasius of Sinai Hexaemeron, OCA 278, Rome 2007, 2-486.

Antiochus Monachus, Pandecta scripturae sacrae, PG 89, 1428-1849.

Apophthegmata Patrum. Collectio alphabetica, PG 65, 71-440, thum. M. Borkowska: Apoftegmaty Ojców Pustyni, t. 1: Gerontikon, ŹM 4, Kraków 1994.

Augustinus Hipponensis, Contra Faustum, ed. J. Zycha, CSEL 25, Wien 1891, 251-797.

Basilius Magnus, Commentarius in Isaiam, PG 30, 118-668.

Clemens Alexandrinus, Stromata, ed. O. Stählin - L. Früchtel, GCS 52, Leipzig 1960², 3-102; O. Stählin - L. Früchtel - U. Treu, GCS 17, Berlin 1970², thum. J. Niemirska-Pliszczyńska: Klemens Aleksandryjski, Kobierce zapisków filozoficznych dotyczqcych prawdziwej gnozy, t. 1-2, Warszawa 1994.

Cyrillus Alexandrinus, Glaphyra in Pentateuchum, PG 69, 9-677. 
Dorotheus Gazaeus, Doctrinae diversae, ed. L. Regnault - J. de Préville, SCh 92, Paris 1963, 146-486, thum. M. Borkowska: Doroteusz, Nauki, w: Doroteusz z Gazy, Pisma ascetyczne, ŹM 51, Kraków 2010, 73-250.

Ephraem Syrus, Capita centum. Quomodo quis humilitatem sibi comparet, ed. K.G. Phrant-

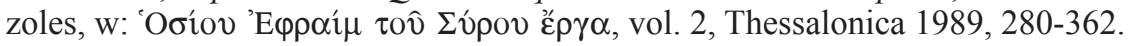

Evagrius Ponticus, De octo spiritibus malitiae, PG 79, 1145-1164, tłum. L. Nieścior: Ewagriusz z Pontu, $O$ ośmiu duchach zła, w: Ewagriusz z Pontu, Pisma ascetyczne, t. 1, ŹM 18, Kraków 2007², 405-436.

Evagrius Ponticus, De oratione, PG 79, 1165-1200.

Evagrius Ponticus, Kephalaia gnostica, ed. A. Guillaumont: Les six Centuries des 'Képhalaia gnostica' d'Évagre le Pontique. Édition critique de la version syriaque commune et édition d'une nouvelle version syriaque, intégrale, avec une double traduction française, Paris 1958.

Gregorius Magnus, Moralia in Iob, ed. M. Adriaen, CCL 143, 143A, 143B, Turnhout 1979-1985, tłum. zbiorowe: Moralia. Komentarz do Księgi Hioba, ŹM 39, t. 1: I-V, Kraków - Tyniec 2006; ŹM 41, t. 2: VI-X, Kraków - Tyniec 2006; ŹM 44, t. 3: XI-XVI, Kraków - Tyniec 2007; ŹM 63, t. 4: XVII-XXII, Kraków - Tyniec 2013; ŹM 75, t. 5: XXIII-XXVII, Kraków - Tyniec 2015; ŹM 77, t. 6: XXVIII-XXXII, Kraków - Tyniec 2016; ŹM 78, t. 7: XXXIII-XXXV, Kraków - Tyniec 2016.

Hieronymus, Commentarii in Ezechielem, ed. F. Glorie, CCL 75, Turnhout 1964, 3-743.

Hieronymus, Liber interpretationis hebraicorum nominum, ed. P. de Lagarde, CCL 72, Turnhout 1959, 59-161.

Isidorus HisPalEnsis, Mysticorum expositiones sacramentorum seu Quaestiones in Vetus Testamentum, PL 83, 207-424.

JoAnnes Damascenus, Sacra parallela (recensiones secundum alphabeti litteras dispositae, quae tres libros conflant), PG 95, 1040-1588; 96, 9-441.

Nilus Ancyranus, De vita monastica, ed. P. Bettiolo, w: Gli scritti siriaci di Nilo il Solitario, Leuven 1983, 75-124.

NiLus Ancyranus, Epistulae, PG 79, 81-581.

Nilus Ancyranus, Liber de monastica exercitatione, PG 79, 720-809, tłum. L. Nieścior, w: Nil z Ancyry, Pisma ascetyczne, ŹM 46, Kraków 2008, 61-150.

Origenes, In Genesim homiliae, ed. W.A. Baerhens, GCS 29, Leipzig 1920, 1-144.

ORIGENES, Adnotationes in Deuteronomium (fragmenta e catenis), PG 17, 24-36.

ORIGENES, Homiliae in Job (fragmenta in catenis, typus I), PG 12, 1032-1049.

Origenes, Homiliae in Job (fragmenta in catenis, typus II), PG 17, 57-105.

ORIGENES, Selecta in Ezechielem (fragmenta e catenis), PG 13, 768-825.

Philo Alexandrinus, De cherubim, éd. J. Gorez, w: Les oeuvres de Philon d'Alexandrie, No 3, Paris 1963.

Philo Alexandrinus, De congressu eruditionis gratia, ed. P. Wendland, w: Philonis Alexandrini opera quae supersunt, ed. L. Cohn - P. Wendland, vol. 3, Berolini 1898, 72-109.

Philo Alexandrinus, De ebrietate. De sobrietate, éd. J. Gorez, w: Les oeuvres de Philon d'Alexandrie, $\mathrm{N}^{\mathrm{o}}$ 11-12, Paris 1962.

Philo Alexandrinus, De fuga et inventione, éd. E. Starobinski-Safran, w: Les oeuvres de Philon d'Alexandrie, $\mathrm{N}^{\circ} 17$, Paris 1970.

Philo Alexandrinus, De gigantibus, éd. A. Mosès, w: Les oeuvres de Philon d'Alexandrie, $\mathrm{N}^{\mathrm{o}}$ 7-8, Paris 1963, 19-56.

Philo Alexandrinus, De migratione Abrahami, éd. J. Cazeaux, w: Les oeuvres de Philon d'Alexandrie, $\mathrm{N}^{\mathrm{o}}$ 14, Paris 1965, 94-242. 
Philo Alexandrinus, De somniis, éd. P. Savinel, w: Les oeuvres de Philon d'Alexandrie, $\mathrm{N}^{\mathrm{o}} 19$, Paris 1962.

Philo Alexandrinus, Legum allegoriarum libri I-III, ed. L. Cohn, w: Philonis Alexandrini opera quae supersunt, ed. L. Cohn - P. Wendland, vol. 1, Berolini 1896, 61-169, thum. L. Joachimowicz: Filon Aleksandryjski, Alegorie praw, w: Filon Aleksandryjski, Pis$m a$, t. 1, Warszawa 1986, 83-192.

Philo Alexandrinus, Quod deterius potiori insidiari soleat, éd. I. Feuer, w: Les oeuvres de Philon d'Alexandrie, $\mathrm{N}^{\circ}$ 5, Paris 1965.

Plato, Leges, ed. J. Burnet, Platonis opera, vol. 5, Oxford 1907 (repr. 1967).

\section{Opracowania}

Bosak Cz., Wszystkie miejsca biblijne. Stownik i konkordancja, t. 1-2, Kraków 2017.

CALABI F., Les sacrifices et leur signification symbolique chez Philon d'Alexandrie, w: "Car c'est l'amour qui me plaît, non le sacrifice...»: recherches sur Osée 6:6 et son interprétation juive et chrétienne, éd. E. Bons, Leiden - Boston 2004, 97-117.

FERNÁNDEZ M.N., Rewritten Bible or imitatio?: the vestments of the high-priest, w: Studies in the Hebrew Bible, Qumran, and the Septuagint presented to E. Ulrich, ed. W. Flint - E. Tov - J.C. VanderKam, Boston 2006, 321-336.

Hilgert E., The dual image of Joseph in Hebrew and early Jewish literature, „Biblical Research" 30 (1985) 5-21.

Kerns L., Soul and passions in Philo of Alexandria, StPatr 63 (2013) 141-154.

Kоoтen G.H. van, The anthropological trichotomy of spirit, soul and body in Philo of Alexandria and Paul of Tarsus, w: Anthropology in the New Testament and its ancient context: papers from the EABS-meeting in Piliscsaba/Budapest, ed. M. Labahn - O. Lehtipuu, Leuven 2010, 87-119.

Laporte J., Sacrifice and forgiveness in Philo of Alexandria, „The Studia Philonica Annual" 1 (1989) 34-42.

LAPORTE J., Sacrifice in Origen in the light of Philonic models, w: Origen of Alexandria: his world and his legacy, ed. Ch. Kannengiesser - W.L. Petersen, Notre Dame (Ind.) 1988, 250-276.

LAPORTE J., The high priest in Philo of Alexandria, „The Studia Philonica Annual” 3 (1991) 71-82.

LieBer A., Between motherland and fatherland: diaspora, pilgrimage and the spiritualization of sacrifice in Philo of Alexandria, w: Heavenly tablets: interpretation, identity and tradition in ancient Judaism, ed. L.R. LiDonnici - A. Lieber, Leiden - Boston 2007, 193-210.

Robertson P.M., Toward an understanding of Philo's and Cicero's treatment of sacrifice, „The Studia Philonica Annual” 23 (2011) 41-67.

ToBIN Th., Tradition and interpretation in Philo's portrait of the patriarch Joseph, „Society of Biblical Literature Seminar Papers" 25 (1986) 271-277.

Winston D., Philo of Alexandria on rational and irrational emotions, w: Passions and moral progress in Greco-Roman thought, ed. J.T. Fitzgerald, New York - London 2008, 201-220. 